\title{
Extraction of natural pigments from marine algae
}

${ }^{\text {"1 }}$ Tanveer Alam, ${ }^{2}$ Lubna Najam, ${ }^{3}$ Ahmed Al Harrasi



AbStract. The pigment content in microalgae is a specific feature of each species. Pigments from natural sources are gaining more importance mainly due to health and environmental issues. Algae contain a wide range of pigments. Three major classes of pigments are chlorophylls, carotenoids (carotenes and xanthophylls) and phycobilins (Phycocyanin and phycoerythrin). Phycocyanin and phycoerythrin belong to the major class of phycobilins photosynthetic pigment while fucoxanthin and peridinin belong to carotenoid group of photosynthetic pigment. Macro- and microalgae (including cyanobacteria) have been recognized to provide a wide diversity of metabolites including pigments for energy capture and photo-protection.

KEYwORDS: Chlorophyll; phycobillins; microalgae; cyanobacteria; pigments

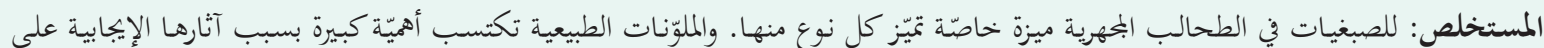

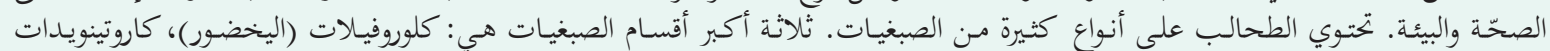



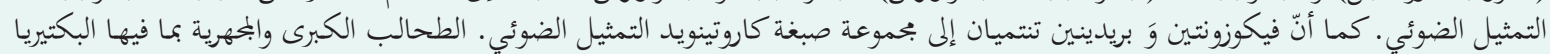

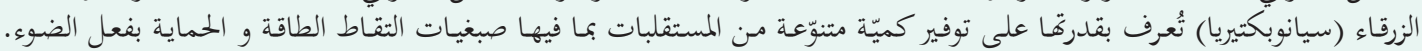

$$
\begin{aligned}
& \text { الكلمات المفتاحية: كلوروفيلات (اليخضور)، فيكوبيلينات، الطحالب البمهرية، البكتيريا الزرقاء (سيانوبكتيريا)، الصبغيات. }
\end{aligned}
$$

\section{Introduction}

$\mathrm{T}$

here are two types of pigments: natural and synthetic. Synthetic pigments are mainly coal tar derivatives made from chemicals which are by products of coal distillation. Many synthetic dyes are controversial and banned in many countries for use in food products because of safety concerns. Use of these synthetic pigments in personal care products also adds health risks. Some of these dyes contain impurities like lead acetate which are toxic to nervous system. Some commonly used synthetic pigments are allergens, irritants and some others are known carcinogens. Thus, there is an increasing demand for natural pigments percieved as less toxic for use in food products, pharmaceuticals and cosmetics. Many plants contain dyes and pigments (other than chlorophyll) which may serve as colorants and may have other roles e.g.; in photosynthesis, insect attractants etc. Natural pigments represent an apparently more sustainable sources of colorants than synthetic counterparts.

Other than higher plants (Angiosperm and gymno-

* Dr. Tanveer Alam ( $\$ ) tanveer@unizwa.edu.om 1"UoN Chair of Oman's Medicinal Plants \& Marine Natural Products, University of Nizwa, Sultanate of Oman . ${ }^{2}$ Department of Chemistry, DAV (PG) College, CCS University, Muzaffar Nagar, UP, India. ${ }^{3 *}$ UoN Chair of Oman's Medicinal Plants \& Marine Natural Products, University of Nizwa, Sultanate of Oman sperm), microalgae are good alternatives of carotenoids and phycobiliproteins for natural colors. Microalgae belong to an heterogenous group of microorganisms. Microalgae are small, unicellular monocellular or multicellular, autotrophic, colorful and grow generally in water and they may be either eukaryotic or prokaryotic. Production of pigments from microalgae has a number of advantages such as cheaper and easy production, easier extraction, higher yields, no lack of raw materials and no seasonal variations. The status of microalgal applications in aquaculture, food, speciality chemicals and environmental applications has been reviewed (Apt and Behrens, 1991; Muller-Feuga, 2000; Pulz et al., 2001; Benemann et al., 2002). In this review our focus is on extraction of microalgal pigments as natural colors, factors affecting their yield, extraction methods and their applications. Major pigments of the microalgae which are used as pigments are carotenoids and phycobiliproteins.

The pigments are characteristic of certain algal groups as indicated in Table 1 (Dring 1982). Chlorophylls and carotenes are generally fat soluble molecules that can be extracted from thylakoid membranes with organic solvents such as acetone, methanol or dimethyl sulfoxide The phycobilins and peridinin, in contrast, are water soluble and can be extracted from algal tissues after the organic solvent extraction of chlorophyll in those tissues. 


\section{Objectives}

Main objective of this work is to summarize the Natural Pigments from Marine species of microalgae.

\section{Common Algal Pigments}

The following pigments are industrially important products.

\section{Chlorophylls}

This photosynthetic green pigment is mainly derived from Chlorella spp. Chlorophyll as a food colorant is found to exhibit anti-mutagenic property (Fig.1,2). This is accomplished by inducing production of Carcinogen Detoxifying Enzymes, and thereby reducing the risk of cancer.

\section{$\beta$-Carotene}

Dunaliella salina a halophilic green algae is used for $\beta$ -carotene production. This pigment is used mainly as food colorant that imparts a Yellow-Orange color. Apart from its use as a colorant, $D$. Solina is used popularly as a nutraceutical additive because it is rich in Vitamin A.

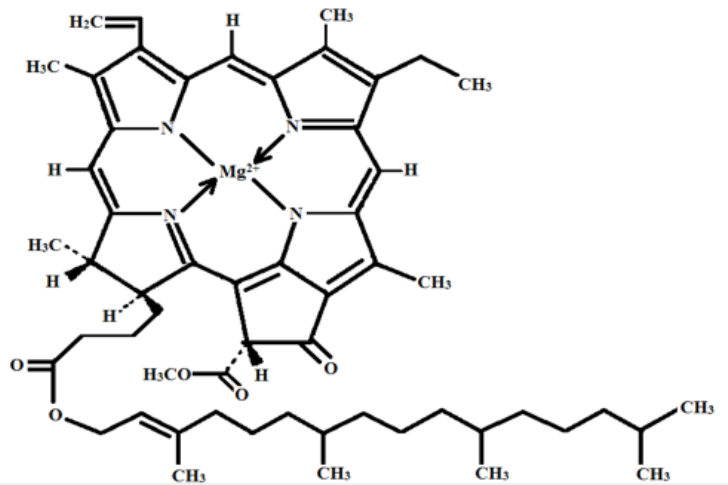

Figure 1. Chemical structure of Chlorophyll $a$.

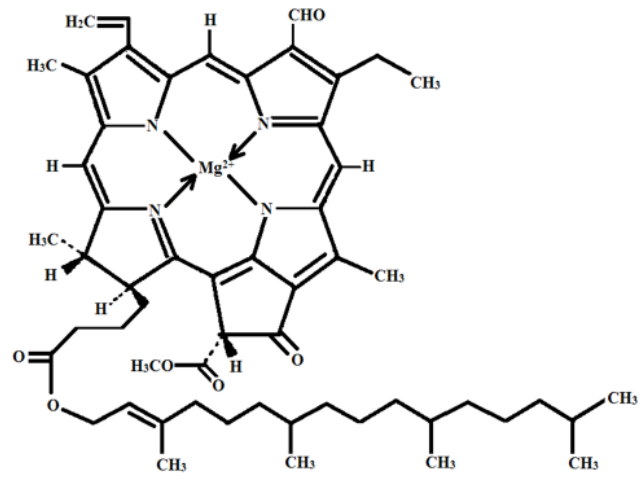

Figure 2. Chemical structure of Chlorophyll $b$.

\section{Fucoxanthin}

This pigment, derived from Phaeophytes, is used for coloring food products brown. This fat reducing properties are well documented.

\section{Peridinin}

Peridinin is a light-harvesting Apocarotenoid, a pigment associated with chlorophyll. The most popular algal source of this pigment is the dinoflagellate, Amphidini-



Figure 3. Chemical structure of $\beta$-Carotene.<smiles>CC1=C(/C=C/C(C)=C/C=C/C(C)=C/C=C/C(C)=C/C=C/C(C)=C/C2=C(C)[C@@]3(C)C(C)(C)C[C@H](O)C[C@@]23C)C(C)(C)C[C@H](O)C1</smiles>

Figure 4. Chemical structure of Antheraxanthin.<smiles>CC1=C(/C=C/C(C)=C/C=C/C(C)=C/C=C/C(C)=C/C=C/C=C(C)/C=C/C=C(\C)C2=C(C)C(=O)[C@H](O)CC2(C)C)C(C)(C)C[C@H](O)C1=O</smiles>

Figure 5. Chemical structure of Astaxanthin.



Figure 6. Chemical structure of Cantaxanthin. 


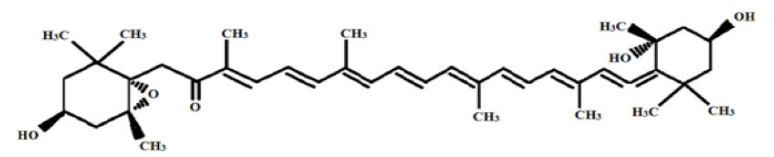

Figure 7. Chemical structure of Fucoxanthinol.

um carterae (Hofmann et.al, 1996) but is found in many other species.

\section{Phycoerythrin}

Red pigment, phycoerythrin is extracted from red algae (Rhodophyta). The species most commonly used for phycoerythrin production is Porphyridium cruentum. It is cultured in artificial seawater with added Potassium Nitrate and optimum temperature of growth for Porphyridium is $21^{\circ} \mathrm{C}$.

\section{Phycocyanin}

Blue pigment, Phycocyanins are derived from blue green algae (Cyanophyta). The most popular algal source of this pigment is Spirulina platensis. It requires an alkaline $\mathrm{pH}$ range of 7.2 to 9.0 and a salinity of $30 \mathrm{~g} / \mathrm{L}$. In the wild, Spirulina grows at $27^{\circ} \mathrm{C}$.

\section{Extraction of Algal Pigment}

Chlorophylls and carotenoids are generally fat soluble molecules and can be extracted from thylakoid membranes with organic solvents such as acetone, methanol or dimethyl sulfoxide.

The phycobilins (Phycoerythrin \& Phycocyanin) and peridinin, in contrast, are water soluble and can be extracted from algal tissues after the organic solvent extraction of chlorophyll in those tissues.

\section{Chlorophylls}

Industrial extraction of these pigments involves homogenization (disintegration) of algal biomass, followed by solvent treatment using an organic solvent mixture (Chloroform-Hexane-Ether-Methanol) (Jaffrey and Humphrey, 1975; Strickland and Parsons, 1968; UNESCO, 1966; Mackinney, 1941; Porra et. al. 1989; Lichtenthaler and Wellburn, 1983; Kaczmar, 2004). Pigments can be extracted from seaweeds by a variety of techniques. It is important to note that light, heat, extremes of $\mathrm{pH}$, and oxygen cause the destruction of pigment extracts. The extracts should be kept cold and worked with in the lowest light possible throughout the procedure. The rationale behind the extraction techniques is to disrupt cell integrity as much as possible, thereby removing

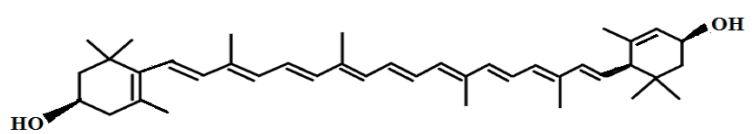

Figure 8. Chemical structure of Lutein.

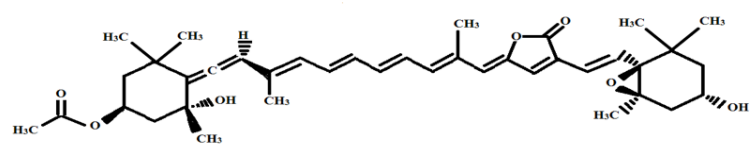

Figure 9. Chemical structure of Peridinin

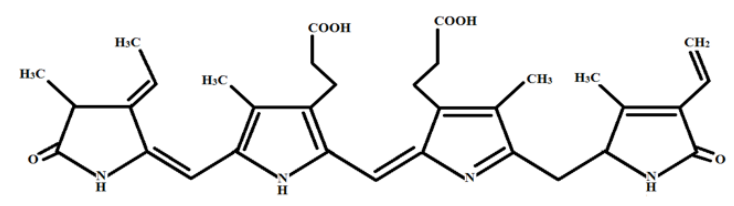

Figure 10. Chemical structure of Phycoerythrin

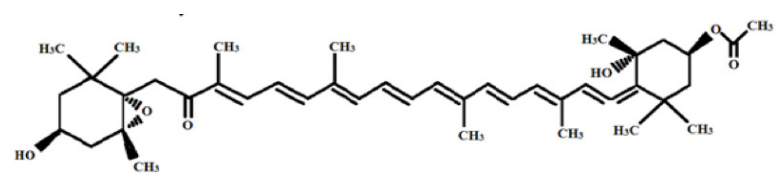

Figure 11. Chemical structure of Chemical structure of Fucoxanthin.

pigment molecules from intrinsic membrane proteins. Freezing the tissue with liquid nitrogen, and grinding the still frozen tissue in with a mortar and pestle or blender, overcomes some of the problems of working with material that produces large amounts of viscous polysaccharides. "Freeze-thawing" tissue also breaks down cellular membranes, but may liberate more polysaccharides. Finely ground tissue can be then homogenized in organic solvent to further disrupt cellular membranes, and to liberate pigment molecules from the light harvesting pigment protein complexes.

Once the pigments are extracted into appropriate 


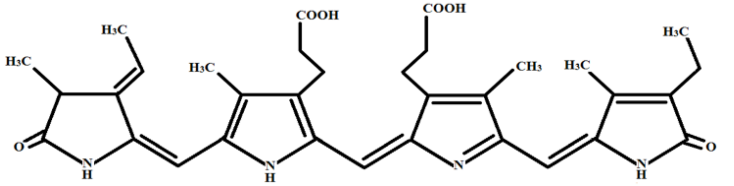

Figure 12. Chemical structure of Phycocyanin.

solvents they can be separated chromatographically by TLC or HPLC for spectral analysis and identification. Pigment concentrations in hydrocarbon solvents can be estimated with various emparical formulae linking absorbances at different wave lenghts to concentrations. However, these formulas are predictive and may overestimate some pigment concentrations (Seely et al. 1972). Uncoupling pigments from the pigment binding proteins can change the absorption patterns of the pigments, resulting in shifts in maxima from 10 to $50 \mathrm{~nm}$, when compared with spectra measured for intact tissues.

\section{Carotenoids}

Carotenoids are lipophilic colored compounds that are found in higher plants (gymnosperms \& angiosperms) and algae as well as in non-photosynthetic organisms like fungi and bacteria. Carotenoids are found in the form of isomers, viz. all trans, 9-cis, 13-cis, 5-cis forms (Wang et al., 1994) More than 600 carotenoids are known (some important ones are, $\beta$-carotene, astaxanthin, cantaxanthin, lutein etc.) and their chemical structure is based on a 40-carbon polyene which is the backbone of the molecule (Fig. 1). The polyene system imparts carotenoids their distinctive molecular structure, their chemical properties and their light absorbing characteristics. The hydrocarbon carotenoids are named carotenes, whereas oxygenated derivatives are known as xanthophylls. In xanthophylls, oxygen can be present as $\mathrm{OH}$ groups (as in canthaxanthin), or as combination of both as in astaxanthin (Huguera-Ciapara et al., 2006).

At present carotenoid production from microalgae refers only to astaxanthin and $\beta$-carotene from Haematococcus pluvialis and Dunaliella salina, respectively. In astaxanthin producing organisms like Phaffia rhodozyma (yeast) or H. pluvialis (algae), carotenoid are located in cytoplasmic lipid globules (Lang, 1968; Johnson and An, 1991). Such extra-plastidic carotenoids are also referred to as secondary carotenoids (Grung et al., 1992). H. pluvialis represents the richest biological source of this pigment and is being cultivated at large scale by several companies, using different approaches. Commercially grown $H$. pluvialis can accumulate $>30 \mathrm{~g}$ of astaxanthin $\mathrm{kg}^{-1}$ dry biomass (Olaizola and Huntley, 2003). Another important source for the production of $\beta$-carotene is the green, unicellular alga Dunaliella sali-
Table 1. Pigment composition of several algal groups (During 1982)

\begin{tabular}{|c|c|c|c|}
\hline Division & Common Name & Botanical Name & Major Pigment \\
\hline Chlorophyta & Green algae & Chlorella sp. & Chlorophyll b \\
\hline Charophyta & Charophytes & Spirogyra & Chlorophyll b \\
\hline Euglenophyta & Euglenoids & Euglena gracilis & Chlorophyll b \\
\hline Phaeophyta & Brown algae & Fucus vesiculosus & $\begin{array}{l}\text { Chlorophyll } \\
\text { c1 + c2, } \\
\text { Fucoxanthin }\end{array}$ \\
\hline Chrysophyta & $\begin{array}{c}\text { Yellow-brown } \\
\text { or } \\
\text { golden brown algae }\end{array}$ & Dunaliella salina & $\begin{array}{l}\text { Chlorophyll } \\
\text { c1 + c2, } \\
\text { Fucoxanthin }\end{array}$ \\
\hline Pyrrhophyta & Dinoflagellates & $\begin{array}{l}\text { Amphidinium } \\
\text { carterae }\end{array}$ & $\begin{array}{l}\text { Chlorophyll } \\
\text { c2, Peridinin }\end{array}$ \\
\hline Cryptophyta & Cryptomonads & Cryptomonas sp. & $\begin{array}{c}\text { Chlorophyll } \\
\text { c2, Phycobilins }\end{array}$ \\
\hline Rhodophyta & Red algae & $\begin{array}{l}\text { Porphyridium } \\
\text { cruentum }\end{array}$ & $\begin{array}{l}\text { Phycoerythrin, } \\
\text { Phycocyanin }\end{array}$ \\
\hline Cyanophyta & Blue-green algae & $\begin{array}{l}\text { Spirulina plat- } \\
\text { ensis }\end{array}$ & $\begin{array}{c}\text { Phycoerythrin, } \\
\text { Phycocyanin }\end{array}$ \\
\hline
\end{tabular}

na. $\beta$-carotene obtained from Dunaliella has many advantages like increased absorption by human body, high efficiency, isomeric composition and it can be produced up to $14 \%$ of dry wt. of the biomass in a very short time (Metting, 1996).

The carotenoid pigment astaxanthin has important applications in the cosmetics, nutraceuticals, food and feed industries. Astaxanthin is a strong colouring agent and a potent antioxidant (Guireen et al., 2003). Contrary to advantages using microalgae as source of natural colourants, some disadvantages have also been reported. Production of microalgae at large scale is associated with disadvantages like little process control (Borowitzka, 1992), high $\mathrm{CO}_{2}$ consumption with low efficiency (Chaumont, 1993), contamination problems and optimal requirements of high amounts of salt, water and solar radiation (Ogbonna and Tanaka, 2000).

For these reasons, alternative strategies/improvement of operating systems such as extensive open ponds (Pulz, 2001, Gomez and Gonzalez, 2004), natural ponds (Gomez and Gonzalez, 2004), paddle wheel driven raceway/ ponds (Pulz, 2001), tubular photo bioreactors (Garcia-Gonzalez et al., 2005), large bags (Pulz, 2001) were suggested and tried to increase the $\beta$-carotene production. Extraction efficiency and productivity of $\beta$-carotene from Dunaliella can be enhanced many folds by using a biphasic bioreactor consisting of an aqueous and a biocompatible organic phase (Hejazi et al., 2002, 2003, 2004). Nowadays industries use closed tubular bioreactors for the production of carotenoids (Gonzalez et al., 2005). This bioreactor has been found preferable for biomass and astaxanthin production from $H$. pluvialis (Lopez et al., 2006).

\section{Extraction of Carotenoid Pigments}

Extraction and purification are two steps in carotenoid production from microalgae (Lee et al., 1999). 


\section{First Step}

Biomass is separated from liquid media by centrifugation. Some alternative methods like flocculation, filtration etc. can also be used (Molina Grima et al., 2004).

\section{Second Step}

Separated biomass needs to be quickly processed to avoid spoiling. The most acceptable methods are spray-drying, drum drying, freeze drying (lyophilization) and sun drying. $\beta$-carotene is extracted from wet Dunaliella paste by different processes, using vegetable oils with or without chemicals, liquid or supercritical $\mathrm{CO}_{2}$ extraction, crystallization and others. The supercritical fluid extraction of carotenoids from the microalgae D. salina, $C$. vulgaris, Spirulina pacifica, and Nannochloropsis gaditana has been reported by many workers with promising results (Lorenzo et al., 1991; Mendes et al., 1995, 2003; Careri et al., 2001; Macias-Sanchez et al., 2005). Dynamic extraction of carotenoids with supercritical $\mathrm{CO}_{2}$ from a marine strain of Synechococcus sp. was investigated with regard to operation pressure and temperature effects on extraction efficiency (Montero et al., 2005). A biphasic aqueous/organic system to force the extraction of $\beta$-carotene into the medium is applied to Dunaliella cultures. In this system, a biocompatible organic solvent is in contact with aqueous phase where the cells develop accumulation of pigments, $\beta$-carotene is continuously extracted into the organic phase overcoming low water solubility of the product and facilitating product recovery and continuous operation (Salter and Kell, 1995; Hejazi et al., 2002, 2003).

\section{Extraction Methods}

The extraction techniques of cell components usually make use of chemical, mechanical and/or enzymatic proceses. In this work only the chemical and mechanical procedures were used, alone or simultaneously, with the aim of maximizing the extraction process efficiency. Figure 13 shows a diagram where the different elementthat were used to extract then identify and quantify pigments in the microalgae, are presented under a structured sequence. The following methods were used to analyze the algal pigments in different extracts. (Table 2, 3 \& 4)

\section{Thin Layer Chromatography Concentration of Carotenoid}

The carotenoid content of seaweeds was determined by the method of Kirk and Allen, 1965. The extract that was used for the chlorophyll estimation was used for carotenoid estimation also. The same chlorophyll extract was measured at 480nm in UV-spectrophotometer to estimate the carotenoid containing the following formula (Eq. 1).

$$
\begin{aligned}
\text { Carotenoid }(\mu \mathrm{g} / \mathrm{g}) & \text { Eq. }(1) \\
= & \mathrm{A} 480+(0.114 \times \mathrm{A} 663)-(0.638 \times \mathrm{A} 645) \\
& \mathrm{A}=\text { Absorbance at respective wavelengths }(\mathrm{nm}) .
\end{aligned}
$$

\section{Applications of Carotenoids}

Nutritional Value: Most of the natural pigments have high nutritional value unlike their synthetic counterparts (Jin et al., 2003) because synthetic pigments con-



Figure 13. Items tested to compare different methods of pigments evaluation. Abbreviations: St : Standard, U: Ultrasound, F: Freezing/Unfreezing, FN: Freezing/Unfreezing with liquid $\mathrm{N}_{2}$ 
Table 2. Empirical equations used to evaluate the concentration of pigments using methanol, acetone and ethanol as extraction solvent.

\begin{tabular}{|c|c|}
\hline \multicolumn{2}{|l|}{ Acetone } \\
\hline Jeffrey and Humphrey (1975) & $\mu g$ Chlorophyll $/ m L$ medium $=(11.85$ A664 - 1.54 A647 - 0.08 A630 $) v /(l \mathrm{~V})$ \\
\hline Strickland and Parsons (1968) & $\mu g$ Chlorophyll $/ \mathrm{mL}$ medium $=(11.66$ A665 - 1.31 A645 - 0.14 A630 $) v /(\mathrm{lV})$ \\
\hline UNESCO (1966) & $\mu g$ Chlorophyll $/ m L$ medium $=(11.64$ A663 - 2.16 A645 - 0.10 A630) $v /(l \mathrm{~V})$ \\
\hline \multicolumn{2}{|l|}{ Methanol } \\
\hline Mackinney (1941) & $\mu g$ Chlorophyll/mL medium $=13.43 \mathrm{A665} v /(\mathrm{lV})$ \\
\hline Porra et.al. (1989) & $\mu$ Chlorophyll/ mLmedium $=(16.29$ A665 - 8.54 A652) $v /(\mathrm{lV})$ \\
\hline Lichtenthaler (1983) & $\begin{array}{c}\mu g \text { Chlorophyll/mL medium }=15.65 \text { A666 } \\
\mu g \text { total carotenoids } / m L \text { medium }=[(1000 \text { A470 - 44.76 A666)/221] }\end{array}$ \\
\hline \multicolumn{2}{|l|}{ Ethanol } \\
\hline Kaczmar (2004) & $\mu g$ Chlorophyll $/ m L$ medium $=(11.64$ A663 - 2.16 A645 - 0.10 A630) $v /(l \mathrm{~V})$ \\
\hline
\end{tabular}

$A$ is the absorbance at respective wave lengths $(\mathrm{nm}), v$ means the volume of solvent used $(\mathrm{mL}), l$ is the spectrophotometric cell length $(\mathrm{cm})$ and $V$ is the sample volume $(\mathrm{mL})$.

tain mainly trans-forms and natural pigments cis-form

(Von Laar et al., 1996).

Antioxidant and anticancer properties: $\beta$-carotene has been shown to have antioxidant and anticancer properties (Becker, 2004).

Pigmentation in fish: Major application of astaxanthin carotenoid is as pigmentation source in aquaculture, primary salmon trout and red sea bream (Guerin et al., 2003; Cysewski and Lorenz, 2004).

Eco-friendliness: The process of manufacturing of natural pigments from algae does not involve the application of hazardous chemicals. The majority of the biomass are biodegradable and can also be reused as fodder, bio-fertilizers, etc.

Non-Toxicity and non-carcinogenicity: Natural pigments derived from algae have been certified as safe for application as food colorants.

Table 3. $R_{f}$ Values of different pigments

\begin{tabular}{|c|c|c|c|}
\hline S. No. & Pigment & $R_{f}$ Value & Solvent System \\
\hline 1 & Chlorophyll a & 0.68 & $\begin{array}{c}7: 3 \\
\text { (Petroleum ether : Acetone) }\end{array}$ \\
\hline 2 & Chlorophyll b & 0.54 & $\begin{array}{c}7: 3 \\
\text { (Petroleum ether : Acetone) }\end{array}$ \\
\hline 3 & Chlorophyll c & 0.03 & $\begin{array}{c}7: 3 \\
\text { (Petroleum ether : Acetone) }\end{array}$ \\
\hline 4 & $\beta$-carotene & 0.94 & $\begin{array}{c}7: 3 \\
\text { (Petroleum ether : Acetone) }\end{array}$ \\
\hline 5 & Fucoxanthin & 0.51 & $\begin{array}{c}7: 3 \\
\text { (Petroleum ether : Acetone) }\end{array}$ \\
\hline 6 & Lutein & 0.43 & $\begin{array}{c}7: 3 \\
\text { (Petroleum ether : Acetone) }\end{array}$ \\
\hline 7 & Violaxanthin & 0.22 & $\begin{array}{c}7: 3 \\
\text { (Petroleum ether : Acetone) }\end{array}$ \\
\hline 8 & Neoxanthin & 0.08 & $\begin{array}{c}7: 3 \\
\text { (Petroleum ether : Acetone) }\end{array}$ \\
\hline
\end{tabular}

Dyes: Chlorophyll Derivatives (Chlorophyllin) are used for dyeing of fabrics such as wool, acetate derivatives and cotton.

Pharmaceuticals: $\beta$-carotene has market applications like food coloring agent, as provitamin A (retinol) in food and animal feed, as an additive to cosmetics and multivitamin preparations and as a health food product under the antioxidant claim (Johnson and Schroeder, 1996; Edge et al., 1997).

Cosmetics: Algal pigments are used for adding exotic pigments to soaps, shampoo, hand wash. Macroalgae are a source of good pigments for various hair coloring

Table 4. Wavelength maxima for pigments in various solvents.

\begin{tabular}{crrr} 
S. No. & Pigment & Wavelength maxima & Solvent \\
1 & Chlorophyll $a$ & $428.5,660.5$ & diethyl ether \\
2 & Chlorophyll $c 1$ & 629.1 & $100 \%$ acetone \\
33 & Chlorophyll $b$ & $452.5,642$ & diethyl ether \\
4 & Chlorophyll $c 2$ & 630.6 & $90 \%$ acetone \\
\hline 5 & Chlorophyll $c 2$ & 629.6 & $100 \%$ acetone \\
6 & Chlorophyll $c 2$ & 630.9 & $90 \%$ acetone \\
7 & Chlorophyll $c$ & 447,533 or 449,635 & $90 \%$ acetone \\
8 & B carotene & 452,470 & Ethanol \\
9 & Lutein & 446,474 & Ethanol \\
10 & Violaxanthin & 442,470 & Ethanol \\
11 & Neoxanthin & 437,466 & Ethanol \\
12 & Myxoxanthophyll & $445,471,503$ & Ethanol \\
13 & Siphonoxanthin & 455 & Ethanol \\
14 & Peridinin & 455 & Ethanol \\
\hline
\end{tabular}


products due to their long lasting properties.Xanthophylls, astaxanthin has many applications in cosmetics products.

Paint Additives: Beer yeast diatoms are also used in paint additives, other than algal pigments, due to the iridescent nature of their silica shells.

Feed industries: Xanthophylls, astaxanthin has many applications in feed industries like as poultry. Major application of this carotenoid is the pigmentation in egg yolk.

\section{Phycobiliproteins}

\section{Structure of Phycobiliproteins}

The phycobiliproteins are antennae protein pigments found in cyanobacteria, rhodophytes, cryptomonads and cyanelles (Glazer, 1994). The phycobiliproteins are present as phycobilisomes anchored on the thylakoid membranes and lie adjacent to the photosynthetic reaction centre of the PS II in cyanobacteria and red algae. These chromoproteins are classified into 3 groups based on the presence of different chromophores among them (Gantt, 1980, 1994; Glazer, 1985; Zilinskas, 1986; Rowan, 1989; Sidler 1994; Mac Coll, 1998; Ducret et al., 1998). These groups are (1) Phycoerythrin (PE) $\lambda \max$ 480 nm-570 nm; (2) Phycocyanin (PC) $\lambda \max 590-630$ $\mathrm{nm}$ and phycoerythrocyanin (PEC) $\lambda \max 630-665 \mathrm{~nm}$ (3) Allophycocyanin (APC) $\lambda \max 620-665 \mathrm{~nm}$. Core of phycobiliproteins is composed of allophycocyanin from which arise six rods of varying length consisting of phycocyanins to the proximal side of the core and phycoerythrins to the distal side of the core (Fig. 14).

\section{Extraction and purification meth- ods}

\section{Phycocyanin}

Phycocyanin is water-soluble and can be easily extracted as a protein-pigment complex (Chaiklahan etal., 2012). Phycocyanin was extracted from the wet biomass of Spirulina using the following methods:

Extraction was done using $100 \mathrm{mM}$ phosphate buffer $(\mathrm{pH} 7.0)$ at a ratio of $1: 100(\mathrm{w} / \mathrm{v})$ with continuous stirring at $300 \mathrm{rpm}$ at room temperature for $4 \mathrm{hrs}$. the sample was centrifuges at $4800 \times \mathrm{g}$ for 15 minutes to remove cell debris. The crude extract was first filtered through a $5 \mu \mathrm{m}$ membrane at flow rate of $150 \mathrm{~mL} \mathrm{~min}^{-1}$. and then through $0.8 / 0.2 \mu \mathrm{m}$ membrane at flow rate of $100 \mathrm{~mL}$ $\mathrm{min}^{-1}$. The phycocyanin was then filtered again through a membrane with a molecular cut-off of $50 \mathrm{kDa}$ at $69 \mathrm{kPa}$ and $75 \mathrm{~mL} \mathrm{~min}^{-1}$. Finally the filtrate was lyophilized to get the phycocyanin powder.

Mechanical cell disintegration methods are currently

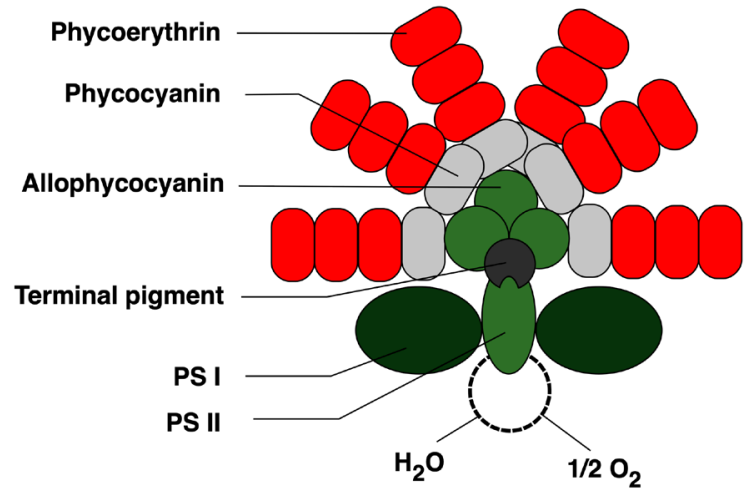

Figure 14. Schematic structure of the pigments in a Phycobilisome.

preferred for large-scale operations (Gacesa and Hubble, 1990; Kula and Schutte, 1987) since a complete disintegration of the biomass is desired, with high product and activity yields.

Allophycocyanin, a bluish green protein and CPC, a blue protein have the major absorption $(\lambda \max )$ in the visible region of $650-655 \mathrm{~nm}$ and $610-620 \mathrm{~nm}$, respectively, with emission light at $660 \mathrm{~nm}$ and $637 \mathrm{~nm}$ respectively (Bryant et al., 1979; Sekar and Chandramohan, 2007). Determinations of these phycobiliproteins by spectrophotometry have been assessed by different authors (Furuki etal., 2003; Chaiklahan etal., 2012). The purity ratio of the phycocyanin extract is determined by the A620/A280 ratio. High purity in the extract refers to high purity ratios (Chaiklahan etal., 2012). Absorbance ratio $\geq 0.7$ refers to food grade pigment, while reagent and analytical grade correspond to 3.9 and $\geq 4.0$ respectively (Borowitzka, 2013).

\section{C-phycocyanin concentration}

The C-phycocyanin concentration (CPC) in $\mathrm{mg}^{\mathrm{mL}} \mathrm{m}^{-1}$ was calculated from the optical densities at 652 and 620 nm, using Eq. 2 (Bennett and Bogorad, 1973):

$$
\mathrm{CPC}=(\mathrm{OD} 620-0.474 \mathrm{OD} 652) / 5.34
$$

Extraction yield: the extraction yield was calculated using Eq. 3 (Silveira et al., 2007).

$$
\text { Yield }=(\mathrm{CPC}) \mathrm{V} / \mathrm{DB}
$$

where Yield is the extraction yield of phycocyanin in mg of C-phycocyanin /dry biomass ( $\mathrm{g}$ ), $\mathrm{V}$ is the solvent volume $(\mathrm{mL})$ and DB is the dry biomass $(\mathrm{g})$.

Calculation of Phycocyanin content (C-PC): (Kursar and Alberte 1983)

The C-PC and APC concentration $(\mu \mathrm{g} / \mathrm{ml})$ were de- 
termined spectrophotometrically from

Equations 1 and 2.

$$
\begin{aligned}
& C-P C=166(\mathrm{~A} 618)-108(\mathrm{~A} 650) \\
& \mathrm{A}-\mathrm{PC}=200(\mathrm{~A} 650)-52.3(\mathrm{~A} 618)
\end{aligned}
$$

Where A refers to absorption at the indicated wave lengths

\section{Phycoerythrin}

Phycoerythrin is a red coloured phycobiliprotein with absorption maxima range at $565 \mathrm{~nm}$. Purity is usually determined as the absorbance ratio of A565/A280 which defines the relationship between the presence of phycoerythrin and other contaminating proteins. A purity ratio A565/A280 >4 corresponds to diagnostics and pharmaceutical grade phycoerythrin (Benavides and Rito-Palomares, 2004).

Phycoerythrin is an intracellular protein, the general purification process relies in three stages: 1 . protein extraction by cell disruption, 2. primary recovery and 3. purification. Disruption methods like sonication, mechanical maceration and lysozyme treatment have been successfully used to extract phycoerythrin from microalgae. Choosing the right cell disruption method has a significant impact in the recovery of the overall process.

Benavides and Rito-Palomares (2006) used aqueous two-phase system (ATPS) to concentrate and purify phycoerythrin. Aqueous two-phase system is an advantageous technique due to its biocompatibility and can easily be scaled. The authors found that it is possible to concentrate phycoerythrin in the PEG-rich top phase using a PEG 1450-phosphate system. The system constructed with a volume ratio (Vr) of 1, PEG 1450 of $24.9 \%(\mathrm{w} / \mathrm{w})$, phosphate concentration of $12.6 \%(\mathrm{w} / \mathrm{w})$ and $\mathrm{pH}$ value of 8 allowed the recovery of phycoerythrin with a 2.9 purity ratio.

Purification is achieved by chromatographic methods like ion exchange chromatography, hydroxyapatite chromatography, gel filtration and expanded bed absorption chromatography.

Calculation of Phycoerythrin content (PE): (Beer and Eshel, 1985)

The following equations are proposed for correct calculations of pigment concentrations (E, phycoerythrin; $\mathrm{C}$, phycocyanin, $\mathrm{mg} \mathrm{ml}-1$ in red algal crude extracts:

$$
\begin{aligned}
& \mathrm{PE}(\mathrm{mg} / \mathrm{ml}) \\
& =[(\mathrm{A} 564-\mathrm{A} 592)-(\mathrm{A} 455-\mathrm{A} 592) \times 0.2] \times 0.12 \\
& \mathrm{C}(\mathrm{mg} / \mathrm{ml}) \\
& =[(\mathrm{A} 618-\mathrm{A} 645)-(\mathrm{A} 592-\mathrm{A} 645) \times 0.15] \times 0.15
\end{aligned}
$$

Where A refers to absorption at the indicated wave lengths.

\section{Applications}

In Food Coloring: One of the most important application of phycocyanin is its use in food items. It is used as a colourant in chewing gums, popscicles, candies, soft drinks, dairy products and cosmetic also in the industry for lipsticks and eye liners. The major organisms exploited are Spirulina for phycocyanin and the red alga Porphyridium for phycoerythrin (Roman et al., 2002).

Dyes: Phycobiliproteins are used for dyeing of fabrics such as wool and cotton in Japan, Thailand and China. Phycocyanin derived from S. platensis is used as a natural pigment in food items such as chewing gums, dairy products and jellies (Santago-Santos et al., 2004), as a dye in pharmaceutical and cosmetic industry (Batista et al., 2006). Pure phycobiliproteins are also widely used as fluorescent labeling agents (Glazer, 1994; Telford et al., 2001). Due to their antioxidant and anti-inflammatory properties, both C-PC and APC are also potential therapeutic agents. (Zhang et al., 2000, Romay et al., 2003).

Phycocyanin colorants in general are non-toxic and non-carcinogenic. Uses of phycocyanin in foods include the coloring of fermented milk products, ice creams, chewing gum, soft drinks, alcoholic drinks, desserts, sweet cake decoration, and milk shakes.

\section{Conclusion}

Important pigments (chlorophyll $a, b$ and $c$, $\beta$-carotene, astaxanthin, xanthophylls, and phycobiliproteins) are produced by many microalgae. Synthetic pigments are used in food, cosmetics, beverages, nutraceutical and pharmaceutical industries. Synthetic pigments are having harmful effects, natural pigments become an attractive option from microalgal pigments. Though algal pigments have the drawback of unstable at high temperature, an effective solution involves using thermophilic algal pigments. Due to increased interest in bio-fuels and food supplements of algal origin, in the recent times, there is widening scope for industries to exploit the availability of other algal products, mainly dyes, fodder and bio-plastics. Investing in the fields of algal pigments production would both increase profitability and reduce wastage of resources (in the form of expelled biomass used as bio fertilizers).

\section{Acknowledgment}

Authors are thankful to MD Mr. C A Anzar, of Olive Lifesciences Pvt. Ltd., for providing the infrastructure and necessary research facilities to carry out the research work on natural food colours from marine species. 


\section{References}

Apt KE, Behrens PW. 1999. Commercial developments in microalgal biotechnology. Journal of Phycology 35:215-226.

Batista, AP, Raymundo A, Sousa I, Empis J. 2006. Rheological characterization of coloured oil in water food emulsions with lutein and phycocyanin added to the oil and aqueous phases. Food Hydrocolloids 20: 4452 .

Becker W. 2004. The nutritional value of microalgae for aquaculture . In: A. Richmond (ed.). Microalgae for Aquaculture. Handbook of Microalgal Culture. Blackwell, Oxford, London. pp. 380-391.

Beer S, Eshel A. 1985. Determining phycoerythrin and phycocyanin concentrations in aqueous crude extracts of red algae. Australian Journal of Marine and Freshwater Research 36(6): 785-792.

Benavides J, Rito-Palomares M. 2004. Bioprocess intensification: a potential aqueous two-phase process for the primary recovery of B-phycoerythrin from Porphyridium cruentum. Journal of Chromatography B 807:33-38.

Benavides J, Rito-Palomares M. 2006. Simplified twostage method to B-phycoerythrin recovery from Porphyridium cruentum. Journal of Chromatography B 844:39-44.

Benemann JR, Van Olst JC, Massingill MJ, Weissman JC, Brune DE. 2002. 6th ICGGCT, 1-4. Oct, Kyoto, Japan [available at http://www.rite.or.jp/GHGT6/pdf/I5-2. pdf].

Bennett A, Bogorad L. 1973. Complimentary Chromatic Adaptation in a Filamentous Blue Green Alga. The Journal of Cell Biology 58(2): 419-435.

Borowitzka LJ. 1992. Commercial Dunaliella production: history of development. In: TG Villa and J Abalde (eds). Profiles on Biotechnology: Serveeiode Publications, Universidad Santiago de compostela, A Coruna. pp. 235.

Borowitzka MA. 2013. High-value products from microalgae-their development and commercialization. Journal of Applied Phycology 25:743-756.

Bryant D, Guglielmi G, Marsac N, Castets A-M, Cohen-Bazire G. 1979. The structure of cyanobacterial phycobilisomes: a model. Archives of Microbiology 123:113-127.

Careri M, Furlattini L, Mangia A, Musc M, Anklam E, Theobald A, von Holst C. 2001. Supercritical fluid extraction for liquid chromatographic determination of carotenoids in Spirulina pacifica alga: A chemometric approach. Journal of Chromatography A 912: 61-71.

Chaiklahan R, Chirasuwan N, Bunnag B. 2012. Stability of phycocyanin extracted from Spirulina sp.: influ- ence of temperature, $\mathrm{pH}$ and preservatives. Process Biochemistry 47:659-664.

Chaumont, D. 1993. Biotechnology of algal biomass production: a review of systems for outdoor mass culture. Journal of Applied Phycology 5: 593-604.

Cysewski GR, Todd-Lorenz R. 2004. Industrial production of microalgal cell mass and secondary products-species of high potential Haematococcus. In: A. Richmond (ed). Handbook of Microalgal Culture. Biotechnology and Applied Phycology. Blckwell Science, Oxford, UK. pp. 281-288.

Dring MJ. 1982. The Biology of Marine Plants. Edward Arnold. pp 1-8.

Ducret A, Muller SA, Goldie KN, Hefti A, Sidler WA, Zuber H, Engel A. 1998. Reconstitution, characterization and mass analysis of the pentacylindrical allophycocyanin core complex from the cyanobacterium Anabaena sp. PCC 7120. Journal of Molecular Biology 278: 369-388.

Edge R, Mc Garvy DJ, Truscott TG. 1997. The carotenoids as antioxidants-a review. Journal of Photochemistry and Photobiology 141: 189-200.

Furuki T, Maeda S, Imajo S, Hiroi T, Amaya T, Hirokawa T, Ito K, Nozawa H. 2003. Rapid and selective extraction of phycocyanin from Spirulina platensis with ultrasonic cell disruption. Journal of Applied Phycology 15:319-324.

Gacesa, P., J. Hubble. 1900. Tecnología de las Enzimas. Editorial Acribia, Zaragoza.

Gantt, E. 1980. Structure and function of phycobilisomes: Light harvesting pigment complexes in red and blue green algae. International Review of Cytology 66: 45-80.

Gantt, E. 1994. Supramolecular membrane organization . In: D. A. Bryant (ed). The Molecular Biology of Cyanobactria. Kluwer Academic Publications, Netherlands pp, 119-135.

Gomez PL, Gonzalez MA. 2004. Genetic variation among seven strains of Dunaliella salina (chlorophyta) with industrial potential based on RADP banding patterns and on its rRNA sequences. Aquaculture 233:149-162.

Garcia-Gonzalez M, Moreno J, Manzano C, Florencio FJ, Guerrero MG. 2005. Production of Dunaliella salina biomass rich in 9-cis $\beta$-carotene and lutein in a closed tubular photo bioreactor. Journal of Biotechnology 115:81-90

Glazer AN. 1985. Light harvesting by phycobilisomes. Annual Review of Biophysics and Biophysical Chemistry 14: 47-77.

Glazer AN. 1994. Phycobiliproteins a family of valuable widely used fluorophores. Journal of Applied Phycology 6: 105-112. 
Gomez PL, Gonzalez MA. 2004. Genetic variation among seven strains of Dunaliella salina (chlorophyta) with industrial potential based on RADP banding patterns and on its rRNA sequences. Aquaculture 233:149-162.

Grung M., D'souza FML, Borowitzka MA, Jensen SL. 1992. Algal carotenoids 51. Secondary Carotenoids 2. Haematococcus pluvialis aplanospores as a source of (3S, 3'S)-astaxanthin esters. Journal of Applied Phycology, 4: 165-171.

Guerin M, Huntley ME, Olaizola M. 2003. Haematococcus astaxanthin: applications for human health and nutrition. Trends in Biotechnology 21: 210-216.

Hejazi MA, Lamarliere CD, Rocha JMS, ermue M, Tramper J, Wijffels RH. 2002. Selective extraction of carotenoids from the microalga Dunaliella salina with retention of viability. Biotechnology and Bioengineering 79: 30-36.

Hejazi MA, Andrysiewicz E, Tramper J, Wijffels RH. 2003. Effect of mixing rate on $\beta$-carotene production and extraction by Dunaliella salina in two phase bioreactor. Biotechnology and Bioengineering 84: 591 596.

Hejazi MA, Kleinegris D, Wijffels RH. 2004. Mechanism of extraction of $\beta$-carotene from microalga Dunaliella salina in two phase bioreactors. Biotechnology and Bioengineering 88: 593-600.

Hofmann E, Wrench PM, Sharples FP, Hiller RG, Welte W, Diederichs K. 1996. Structural basis of light harvesting by carotenoids: peridinin-chlorophyll-protein from Amphidinium carterae. Science 272 (5269): 1788-1791.

Higuera-Ciapara I, Felix-Valenzuela L, Goycoolea FM. 2006. Astaxanthin: A review of its chemistry and applications. Critical Reviews in Food Science and $\mathrm{Nu}$ trition 46: 185-196.

Jaffry SW, Humphrey GF. 1975. New Spectrophotometric Equations for Determining Chlorophylls a, b, c1 and c2 in Higher Plants, Algae and Natural Phytoplankton. Biochem Physiol Pflanzen 167: 191-194.

Jin ES, Polle JEW, Lee HK, Hyun SM, Chang M. 2003. Xanthophylls in microalgae from Biosynthesis to Biotechnological Mass Production and Applications. Journal of Microbiology and Biotechnology 13: 165174.

Johnson EA, An GH. 1991. Astaxanthin from microbial sources. Critical Reviews in Biotechnology 53:119178.

Johnson EA, Schroeder WA. 1996. Microbial carotenoids. Advances in Biochemical Engineering/ Biotechnology 53:119-178.

Kaczmar 2004. Phytoplankton Pigments. http://water. iopan.gda.pl/ kaczmar/bdo/pigments.htm Cited 15 Nov 2004.
Kirk JTO, Allen RL. 1965. Dependence of chloroplast pigments synthesis on protein synthesis: effect of actidione. Biochemical and Biophysical Research Communication 21(6): 523-530.

Kula MR, Schutte H. 1987. Purification of Proteins and the Disruption of Microbial Cell. Biotechnology Progress 3(1): 31.

Kursar TA, Alberte RS. 1983. Photosynthetic unit organization in red alga: relationship between Light-harvesting pigments and reaction centers. Plant Physiology $72(2): 409-414$

Lang NJ. 1968. Electron microscope studies of extraplastidic astaxanthin in Haematococcus. Journal of Phycology 4: 12-19.

Lee YK, Zhang DH. 1999. Production of astaxanthin by Haematococcus. In: Z. Cohen (ed). Chemicals from Microalgae: Taylor \& Francis: London, U.K. pp. 173195.

Lichtenthaler HK, Wellburn AR. 1983. Determination of total carotenoids and chlorophylls $a$ and $b$ of leaf extracts in different solvents. Biochemical Society Transactions 11: 591-603.

Lopez MC, Sanchez ER, Lopez JL, Fernandez FG, Sevilla JM, Rivas J, Guerrero MG, Grima EM. 2006. Comparative analysis of the outdoor cultures of Haematococcus pluvialis in tubular and bubble column photobioreactors. Journal of Biotechnology 123: 329-342.

Lorenzo TV, Schwartz SJ, Kilpatrick PK. 1991. Supercritical fluid extraction of carotenoids from Dunaliella algae. In: M. A. Hugh (ed). Proceedings of the second international symposium on supercritical fluids, Boston, MA, John Hopkins University, Baltimore, M.D.

Mac Coll R. 1998. Cyanobacterial phycobilisomes. Journal of Structural Biology 124: 311-334.

Mackinney G. 1941. Absorption of light by chlorophyll solutions. Journal of Biological Chemistry 140: 315322

Marcias-Sanchez MD, Mantell C, Rodriguez M, de la Ossa EM, Lubian LM, Montero O. 2005. Supercritical fluid extraction of carotenoids and chlorophyll a from Nannochloropsis gaditana. Journal of Food Engineering 66: 245-251.

Mendes RL, Fernandes HL, Coelho JP, Reis EC, Cabral JMS, Novais JM, Palavra, AF. 1995. Supercritical $\mathrm{CO}_{2}$ extraction of carotenoids and other lipids from Chlorella vulgaris. Food Chemistry 53: 99-103.

Mendes RL, Nobre BP, Cardosa MT, Pereira AP, Palavra AF. 2003. Supercritical carbon dioxide extraction of compounds with pharmaceutical importance from microalgae. Inorganica Chimica Acta 356: 328-334.

Metting FB Jr. 1996. Biodiversity and application of microalgae. Journal of Industrial Microbiology 17: 477489. 
Molina-Grima E, Acien Fernandez FG, Robles Medina A. 2004. Downstream processing of cell-mass and products. In: A. Richmond (ed). Handbook of Microalgal Culture. Biotechnology and Applied Phycology. Blckwell Science, Oxford, U.K. pp 215-251.

Montero O, Macias-Sanchez MD, Lama CM, Lubian, C. Mantell LM, Rodriguez M, Martinez de la Ossa E. 2005. Supercritical $\mathrm{CO}_{2}$ extraction of $\beta$-carotene from a marine strain of the cyanobacterium Synechococcus species. Journal of Agricultural and Food Chemistry 53: 9701- 9707.

Muller-Feuga A. 2000. The role of microalgae in aquaculture: situation and trends. Journal of Applied Phycology 12(3-5): 527-534.

Ogbonna JC, Tanaka H. 2000. Light requirement and photosynthetic cell cultivation; development of processes for efficient light utilization in photo bioreactors. Journal of Applied Phycology 12(3-5): 207-218.

Olaizola M, Huntley ME. 2003. Recent advances in commercial production of astaxanthin from microalgae. In: M. Fingerman, and R, Nagabhushanam, (eds). Biomaterials and Bioprocessing. Enfield Science Publ., pp. 143-164.

Porra RJ, Thompson WA, Kriedemann PE. 1989. Determination of accurate extinction coefficients and simultaneous equations for assaying chlorophylls $a$ and $b$ extracted with four different solvents: verification of the concentration of chlorophyll standards by atomic absorption spectroscopy. Biochimica et Biophysica Acta 975: 384-394.

Pulz O. 2001. Photo bioreactors: Production system for phototrophic microorganisms. Applied Microbiology and Biotechnology 57: 287-293.

Pulz O, Scheibenbogen K, Gross W. 2001. Biotechnology with cyanobacteria and microalgae. In H.J. Rehm; G. Reed, A. Puhler et.al (eds). Biotechnology. 2nd edition Vol. 10 Wiley VCH, Weinheim, Germany. pp. 105-36.

Roman BR, Alvarez-Pez JM, Fernandez FGA, Grima EM. 2002. Recovery of pure B-phycoerythrin from the microalga Porphyridium cruentum. Journal of Biotechnology 93: 73-85.

Rowan KS. 1989. Photosynthetic Pigments of Algae. Cambridge University, Press, New York.

Romay C, Gonzalez R, Ledon N, Remirez D, Rimbau V. 2003. C-Phycocyanin: A biliprotein with antioxidant, anti-inflammatory and neuroprotective effects. Current Protein and Peptide Science 4: 207-216.

Salter GJ, Kell DB. 1995. Solvent selection for whole cell biotransformation in organic media. Critical Reviews in Biotechnology 15: 139-177.

Santiago-Santos M, Ponce Noyola T, Olvera-Ramirez R, Ortega-Lopez J, Canizares-Villanueva RO. 2004. Extraction and purification of phycocyanin from Calo- thrix sp. Process Biochemistry 39: 2047-2052.

Seely GR, Duncan MJ, Vidaver WE. 1972. Preparative and Analytical extraction of pigments from brown algae with dimethyl sulfoxide. Marine Biology 12: 184-188.

Sekar S, Chandramohan M. 2007. Phycobiliproteins as a commodity: trends in applied research, patents and commercialization. Journal of Applied Phycology 20:113-136.

Sidler WA. 1994. Phycobilisome and phycobiliprotein structures. In: Bryant DA (ed) The Molecular Biology of Cyanobacteria, Chap 7, pp 139-216. Kluwer Academic Publishers, Dordrecht, The Netherlands.

Silveira ST, Burkert JFM, Costa JAV, Burkert CAV, Kalil SJ. 2007. Optimization of Phycocyanin Extraction from Spirulina platensis Using Factorial Design. Bioresource Technology 98(8): 1629.

Strickland JD, Parsons TR. 1968. A Practical Handbook of Seawater Analysis, Ottawa 2nd Edition. Fisheries Research Board of Canada 167: 31.

Telford WG, Moss MW, Morseman JP, Allnutt FC. 2001. Cyanobacterial stabilized phycobilisomes as fluorochromes for extracellular antigen detection by flow cytometry. Journal of Immunological Methods 254: 13-30.

UNESCO, Rep. SCOR/UNESCO WG 17, UNESCO, Paris, Determination of Photosynthetic pigments in Seawater, Monographs on Oceanographic Methodology, 1, 11 (1966).

Von Laar J, Stahl W, Bolsen K, Goerz G, Sies H. 1996. $\beta$-carotene serum levels in patients with erythropoietic protophyrin on treatment with the synthetic alltrans isomer or a natural isomeric mixture of $\beta$-carotene. Journal of Photochemistry and Photobiology B: Biology 33: 157-162.

Wang, XD, Krinsky NI, Benotti PN, Russell RM. 1994. Biosynthesis of 9 -cis retinoic acid from 9 -cis- $\beta$-carotene in human intestinal mucosa in vitro. Archives of Biochemistry and Biophysics 313: 150-155.

Zhang S, Yao S, Wang W, Xie J, Zhang J, Zhao J, Jiang L. 2000. Studies on the kinetics of reactions between phycobiliproteins and hydroxyl radicals by a pulse radiolytic technique. Chinese Science Bulletin 45(10): 896-899.

Zilinskas BA, Greenwald LS 1986. Phycobilisome structure and function. Photosynthesis Research 10: 7-35. 